Manuscript received January 16, 2017; accepted for publication November 1, 2017; published online May 16, 2018.

1 Civil, Environmental, and Architectural Engineering Department, The University of Kansas, 1530 W 15th St., Lawrence, KS 66045, USA (Corresponding author) e-mail: nmadan2000@gmail.com, (1) https://orcid.org/0000-00031383-7750

${ }^{2}$ Civil, Environmental, and Architectural Engineering Department, The University of Kansas, 1530 W 15th St., Lawrence, KS 66045, USA
Madan Neupane, ${ }^{1}$ Robert L. Parsons, ${ }^{2}$ and Jie $\mathrm{Han}^{2}$

\section{Rapid Estimation of Fouled Railroad Ballast Mechanical Properties}

\section{Reference}

Neupane, M., Parsons, R. L., and Han, J., "Rapid Estimation of Fouled Railroad Ballast Mechanical Properties," Geotechnical Testing Journal, Vol. 41, No. 4, 2018, pp. 777-786, https://doi.org/10.1520/GTJ20170022. ISSN 0149-6115

\section{ABSTRACT}

Ballast fouling and ballast deterioration are significant maintenance concerns. Ballast fouling occurs because of the wearing of the ballast against the tie and other ballast, along with the intrusion of fines from the subgrade and deposition of coal dust or soil particles from the surface. In this study, the assessment of mechanical properties of fouled ballast using available geotechnical tests is discussed. These mechanical properties include subgrade reaction modulus from static plate loading tests, dynamic deformation modulus from light weight deflectometer (LWD) tests, and California bearing ratio (CBR) from dynamic cone penetrometer (DCP) tests. The test results show similar trends for these mechanical properties, which were determined by varying the fouling amount as well as the moisture content. The mechanical properties first increased with the moisture content up to a certain value and then decreased rapidly after a peak value. This article also discusses the correlations between these mechanical properties developed from the tests.

\section{Keywords}

ballast fouling, field test, mechanical properties, subgrade reaction modulus, plate loading test

\section{Introduction}

Good ballast is characterized by strength, toughness, durability, stability, drainability, workability, availability, low cost, resistance to deformation, and overall economy (Hay 1982). A strong, well-drained ballast layer is an important factor in the reliability and efficiency of rail track performance. The bearing capacity of the ballast relies on frictional interlocking. The void spaces between these interlocking particles provide the pathways for drainage. Hard and durable ballast particles with angular shapes and a rough surface texture can have high strength. The major benefits of the ballast are: (1) it can serve as good drainage, and (2) it has suitable resilient properties for repeated load applications. Rail track ballast may be fouled and degraded because of the intrusion of fine particles from the subgrade or environment as well as particles produced within the layer because of particle breakage. This fouling can cause weak track support and large permanent settlement, thus forcing the limitation of train speed or requiring 
maintenance actions to ensure a safe track condition. This article discusses the evaluation of fouling on mechanical properties using established geotechnical testing methods that are economical, easy to operate, and do not require as much time on the track as many other established methods.

The fine particles, including the broken ballast, the deposited coal dust from the surface, and the migrated soil from the subgrade soil, have the ability to retain moisture and reduce hydraulic conductivity of ballast. These fine particles can be in a slurry form when mixed with a sufficient amount of water, migrate throughout the ballast layer, and fill voids within the ballast. Wallace (2003) and Parsons et al. (2014) found that an increase in the percentage of fines resulted in a decrease in hydraulic conductivity. The accumulation of fine particles can hinder drainage and reduce stability of ballast by loss of friction, subgrade attrition, and ballast deterioration because of delay in dissipation of excess pore water pressure (Indraratna et al. 2006) and create serviceability problems. Read et al. (2010) found that external drainage at sites with fouling appeared to be adequate to remove water from the right-of-way; however, the internal drainage of the ballast section with fouling was inadequate to drain water laterally to the ditches. Furthermore, the ballast particles could become rounded because of abrasion, which reduced the interlocking strength of the ballast layer and resulted in more track deflection, increased rail and tie bending stresses, and compromised track stability.

Earlier researchers investigated the strength and deformation characteristics of coal dust, plastic clay, and rock particle fouled ballast through large direct shear tests and found that the clean ballast had higher shear strength than fouled ballast because of a decrease of the friction angle (Huang, Tutumluer, and Dombrow 2009; Parsons, Rahman, and Han 2012). Similar fouling compositions were tested by Ebrahimi, Tinjum, and Edil (2014) using large scale triaxial tests. They found that increased fouling and moisture caused the accumulation of plastic strain in ballast was due to the lack of contact between large ballast particles, because they were separated by the fouling material. Huang, Tutumluer, and Dombrow (2009) further found that the shear strength decreased significantly for the case of wet coal-fouled samples as compared to the mineral filler and plastic subgrade soil fouled samples. They found that fouling could lead to track distresses while analyzing the coal-fouled ballast by investigating discrete element modeling (DEM) images (Huang and Tutumluer 2011).

The light weight deflectometer (LWD) is a portable device designed to rapidly measure the in situ elastic modulus of soil and is based on measurement of the deflection created by dropping a weight onto a circular plate in contact with the soil. The LWD test was used to predict the subgrade modulus by correlating it with the resilient modulus (Mohammad et al. 2009) and as a modulus-based quality control tool for establishing the target modulus of granular subgrade (Mazari et al. 2016). The modulus estimated by the LWD test is the dynamic deformation modulus $\left(E_{v d}\right)$, which is determined by elastic theory based on the assumption of a homogeneous, isotropic, and linearly elastic half-space medium. The modulus of railroad ballast is influenced by several parameters including stress history, load cycles and stress level, load duration, frequency and load sequence, density, grading, fines content and maximum grain size, aggregate type and particle shape, and moisture content. Among these factors, only the effects of stress and moisture content are consistent (Lekarp, Isacsson, and Dawson 2000).

Railway track bed settlement is complex, as the properties of subgrade soil underlying the track also affect the rate of settlement and partial ballast degradation. The deformation $(\delta)$ created by the applied drop weight force $(F)$ through the circular plate of radius $(r)$ can be calculated using Eq 1 (Mooney and Miller 2009).

$$
\delta=\frac{2 F(1-\nu)}{A G r}
$$

where $G$ and $\nu$ are the shear modulus and Poisson's ratio of the soil, respectively, and $A$ is the contact stress distribution parameter. This relationship can be used to calculate $G$ and then the dynamic deformation modulus $\left(E_{v d}\right)$ by considering the peak applied force $\left(F_{\text {peak }}\right)$ and its corresponding displacement $\left(\delta_{\text {peak }}\right)$ in measured time histories. The influence depth of LWD tests was reported to range from 0.9 to 1.1 times the plate diameter (Mooney and Miller 2009). The LWD test plate diameter varies from $150-300 \mathrm{~mm}$. A schematic diagram of LWD is shown in Fig. 1.

FIG. 1 Schematic diagram of LWD (redrawn after Umashankar, Hariprasad, and Kumar [2016]).

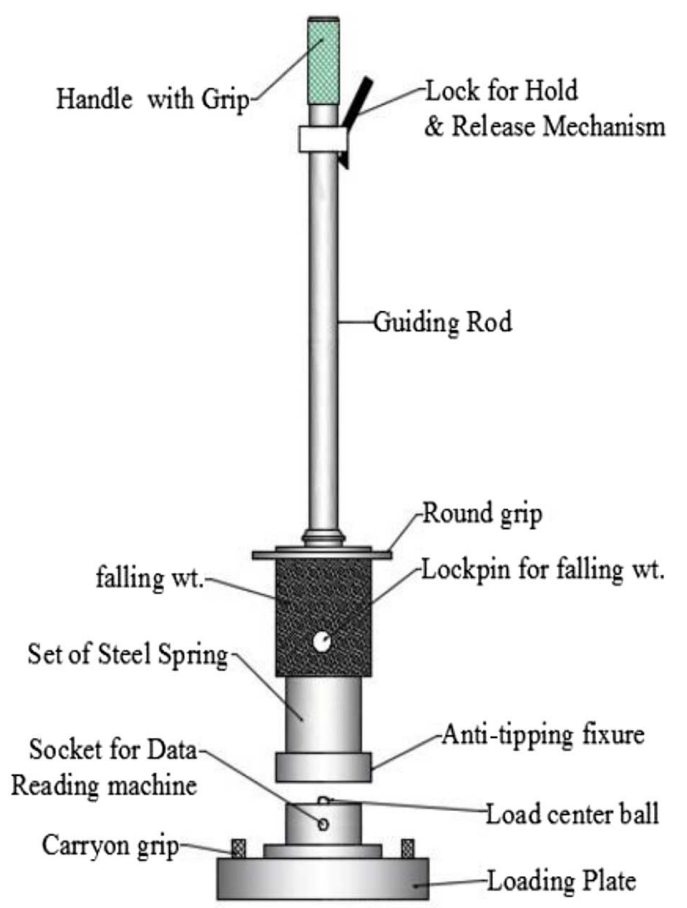


The dynamic cone penetrometer (DCP) is a field tool used to determine the resistance of soil or aggregate by driving a conetipped steel rod with a calibrated sliding weight. The parameter obtained by a DCP test is the dynamic cone penetration index (DCPI), which is defined as the penetration per blow. A higher DCPI indicates lower soil resistance. The DCPI (measured in $\mathrm{mm} / \mathrm{blow}$ ) is correlated with the California bearing ratio (CBR) as follows (Webster, Brown, and Porter 1994).

$$
\mathrm{CBR}=\frac{292}{(\mathrm{DCPI})^{1.12}}
$$

Salgado and Yoon (2003) found that the CBR of a soil increased as its dry unit weight increased. In addition to the dry unit weight, DCPI was a function of moisture content. If the moisture content of a soil increased, the penetration index first decreased and then increased for water contents above the optimum moisture content (Harison 1987; Salgado and Yoon 2003). Ayers, Thompson, and Uzarski (1989) developed a correlation between DCPI and the shear strength of granular soil while Chen et al. (2005) developed a correlation between DCPI and the pavement layer moduli. A schematic diagram of DCP is shown in Fig. 2.

In addition to LWD and DCP tests, static plate loading tests have been conducted to evaluate the subgrade reaction of the ballast. The slope of the load-displacement curve from a plate

FIG. 2 Schematic diagram of DCP (redrawn after Herrick and Jones [2002]).

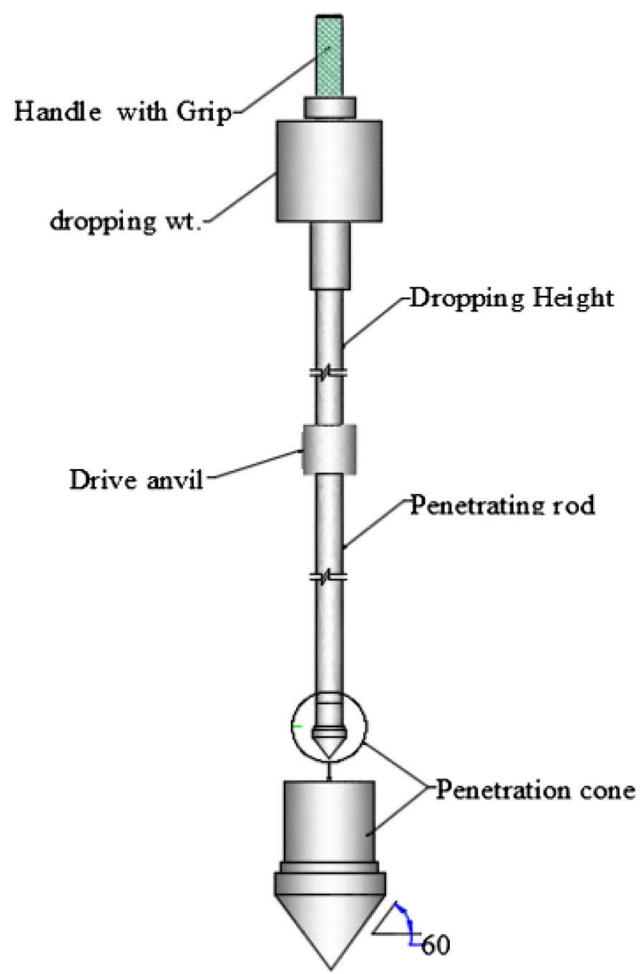

FIG. 3 Schematic diagram of plate loading test

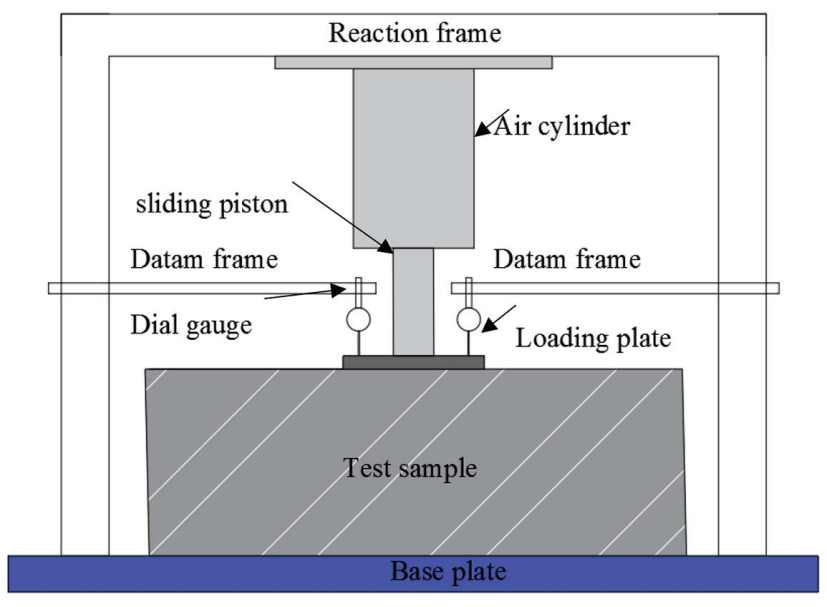

loading test is the subgrade reaction modulus of the fouled ballast. Elastic theory, as shown in Eq 3, can be used to predict the settlement $(s)$ of a rigid surface plate of diameter $(D)$. In the following equation, uniform pressure $(p)$ is applied on a semiinfinite isotropic soil characterized by Young's modulus $\left(E_{s}\right)$ and Poisson's ratio ( $(v)$.

$$
s=\frac{\pi}{4} \frac{D p\left(1-\nu^{2}\right)}{E_{s}}
$$

A schematic diagram of a plate loading test is shown in Fig. 3.

\section{Test Materials}

In this study, the ballast was obtained during an undercutting action from the Burlington Northern and Santa Fe (BNSF) track in Gardner, Kansas. It was composed of heterogeneous igneous rock particles. The ballast was washed over a commercially available wire screen $(1.8 \mathrm{~m}$ by $1.2 \mathrm{~m}$ ) with an opening size of $5.8 \mathrm{~mm}$ to remove the finer particles. The clean ballast had a bulk specific gravity of 2.69 and water absorption of $0.7 \%$. The gradation of the clean ballast is presented in Fig. 4b. The maximum particle size, the mean particle size $\left(d_{50}\right)$, the coefficient of curvature, and the coefficient of uniformity of the clean ballast were $50 \mathrm{~mm}, 28 \mathrm{~mm}$, 1.25 , and 2.77 , respectively.

The subgrade soil, the track dust, and the coal dust were three fouling agents added to the clean ballast to make fouled ballast. The subgrade soil was a clayey soil excavated near the geotechnical laboratory at the University of Kansas. The track dust was an actual fouling material and collected as the residue of the ballast after washing. The track dust consisted primarily of crushed ballast particles, although some clay particles from the subgrade were included. The coal dust was subbituminous coal, originating from Wyoming's Powder River basin. Basic engineering properties of 
FIG. 4 Particle size distributions: (a) fouling agents and (b) clean and fouled ballast.

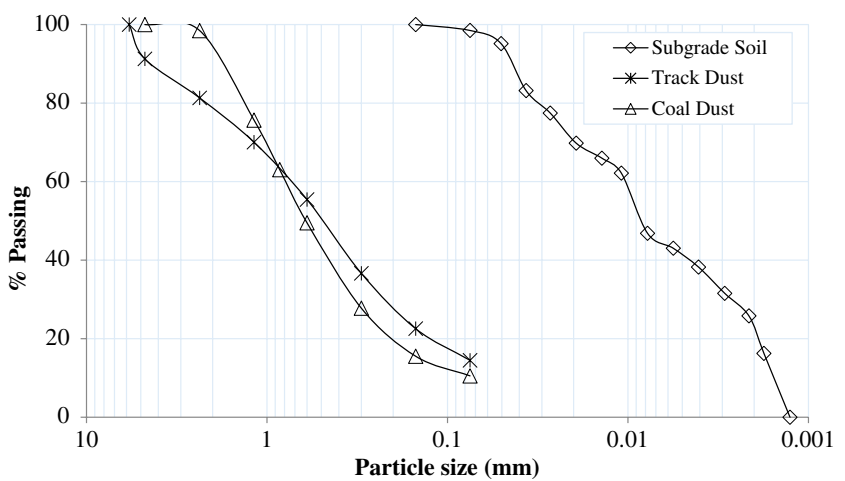

(a)

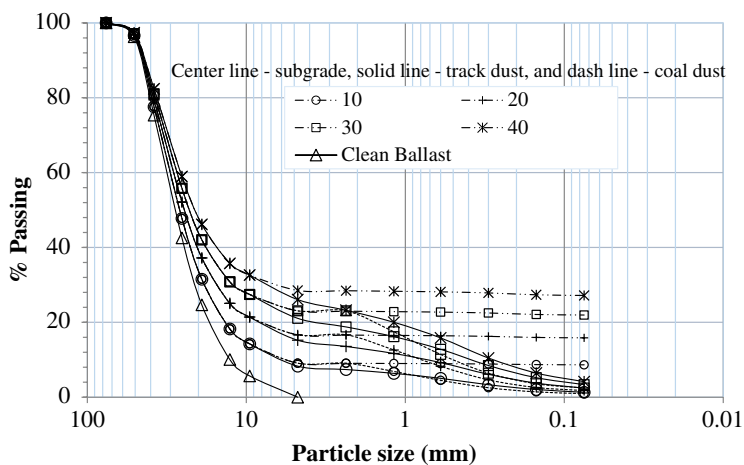

(b)

these fouling agents are presented in Table 1. Fig. 4a presents the particle size distributions of these fouling agents while Fig. $\mathbf{4 b}$ presents the particle size distributions of clean and fouled ballast for different percentages of the fouling agents.

\section{Sample Preparation and Test Setup}

For each type of fouled ballast, samples were prepared with moisture contents ranging from as low as $2 \%$ up to the field capacity of
TABLE 2 Prepared specimen composition.

\begin{tabular}{ll}
\hline Type & \multicolumn{1}{c}{ Sample number and condition } \\
\hline Clean Ballast & One sample \\
Subgrade soil fouled ballast & $\begin{array}{l}\text { Samples with } 10 \%, 20 \%, 30 \% \text {, and } 40 \% \\
\text { fouling by weight }\end{array}$ \\
Track dust fouled ballast & $\begin{array}{l}\text { Samples with } 10 \%, 20 \%, 30 \% \text {, and } 40 \% \\
\text { fouling by weight }\end{array}$ \\
Coal dust fouled ballast & $\begin{array}{l}\text { Samples with } 10 \%, 20 \%, \text { and } 30 \% \text { fouling } \\
\text { by weight }\end{array}$ \\
\hline
\end{tabular}

the fouled ballast, which is defined as the water content held in the soil after excess water drains away naturally. Table 2 contains a summary of the specimens prepared for this study.

The fouled ballast was placed into a test box $810 \mathrm{~mm}$ long by $810 \mathrm{~mm}$ wide and $560 \mathrm{~mm}$ thick in four layers. Fifty drops with a manual hammer of $12.7 \mathrm{~kg}$ were applied on each soil layer with an average fall height of $460 \mathrm{~mm}$. Fig. 5 shows the locations of the LWD, the DCP, and the static plate loading tests within the test box.

A ZFG 3000 (Zorn Instruments GmbH \& Co. KG, Stendal, Germany) light weight deflectometer (LWD) was used to determine the dynamic deformation modulus of the ballast. A 150-mm diameter base plate was used because of the limited space of the test box. The dynamic deformation modulus was measured at Locations E, F, G, and H, as shown in Fig. 5. The LWD test procedure included three seating drops followed by three test drops, in accordance with the test manual recommendation (Zorn Instruments 2011). The average modulus from these three test drops was reported as the dynamic deformation modulus of the ballast.

California bearing ratios (CBRs) of the ballast were estimated using the DCPIs for four locations: K, L, M, and $\mathrm{N}$ as shown in Fig. 5 according to Eq 2. The DCP test was performed to an average depth of $460 \mathrm{~mm}$. Penetration obstruction occurred at several DCP test locations. These obstructed test locations were abandoned, and the tests were repeated at nearby locations.

A small plate loading system was used for the plate loading test. The system had a 150-mm-diameter air cylinder with a

TABLE 1 Basic engineering properties of the fouling agents.

\begin{tabular}{|c|c|c|c|c|c|}
\hline S.N. & Descriptions of Properties & Units & Subgrade Soil & Track Dust & Coal Dust \\
\hline 1 & Fine content ( $<75$ micron) & $\%$ & 95.1 & 14.5 & 10.5 \\
\hline 2 & Maximum particle size & $\mathrm{mm}$ & 0.15 & 5.8 & 4.75 \\
\hline 3 & Average particle size $\left(d_{50}\right)$ & $\mathrm{mm}$ & 0.048 & 0.4 & 0.3 \\
\hline 4 & Coefficient of curvature $\left(C_{c}\right)$ & - & 0.56 & 2.21 & 1.99 \\
\hline 5 & Coefficient of uniformity $\left(C_{u}\right)$ & - & 9.29 & 13.70 & 12.13 \\
\hline 6 & Specific gravity $(G)$ & - & 2.66 & 2.70 & 1.30 \\
\hline 7 & Optimum moisture content & $\%$ & 19.3 & 11.3 & 29.3 \\
\hline 8 & Maximum dry density & $\mathrm{kg} / \mathrm{m}^{3}$ & 1,621 & 1,940 & 932 \\
\hline 9 & Plastic limit & $\%$ & 21 & 14 & 59 \\
\hline 10 & Liquid limit & $\%$ & 43 & 31 & 85 \\
\hline
\end{tabular}


FIG. 5

Test locations for LWD, DCP, and plate loading tests (dimensions in $\mathrm{mm}$ )

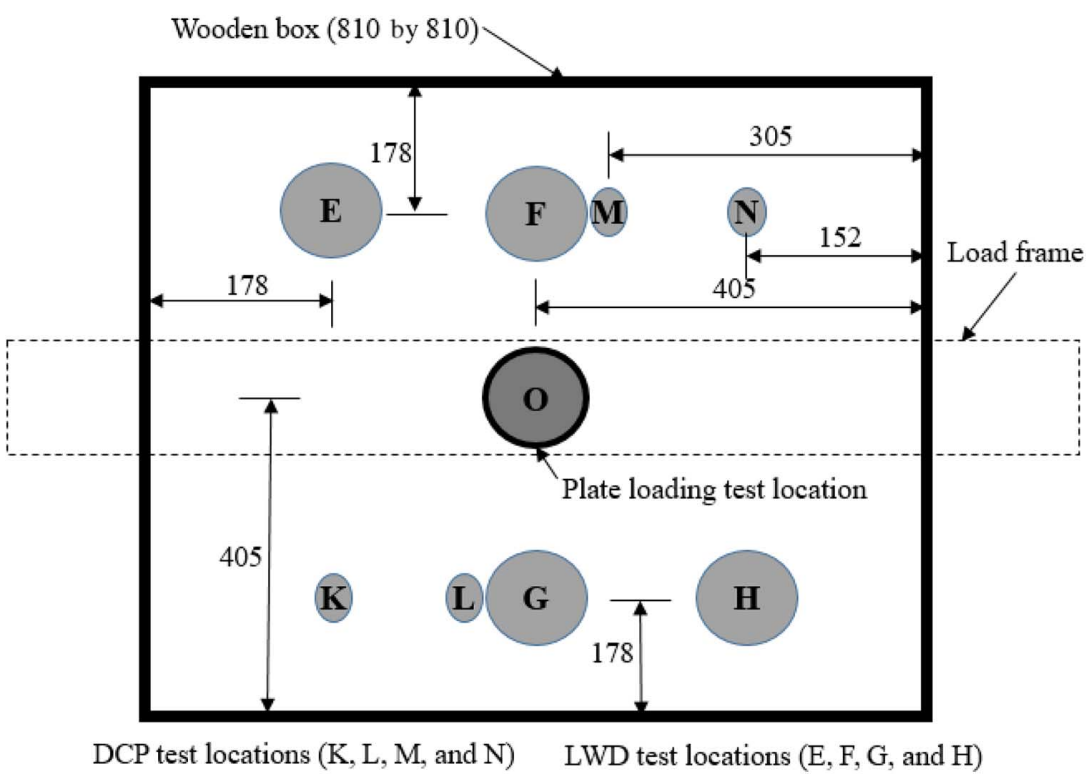

maximum pressure of $830 \mathrm{kPa}$ and a loading plate with a diameter of $150 \mathrm{~mm}$. The test was stopped before it reached the maximum pressure if the displacement exceeded $10 \mathrm{~mm}$ because of the limiting capacity of the air cylinder.

\section{Test Results and Analysis}

\section{CLEAN BALLAST SAMPLES}

The average dry density of the clean ballast was $1,762 \mathrm{~kg} / \mathrm{m}^{3}$, and its corresponding void ratio was 0.54 . The average CBR of the clean ballast was $11.9 \%$ while the dynamic deformation modulus $\left(E_{\mathrm{vd}}\right)$ and the subgrade reaction modulus $(k)$ of the clean ballast samples were 17.3 $\mathrm{MPa}$ and $89.7 \mathrm{MPa} / \mathrm{m}$, respectively.

\section{FOULED BALLAST SAMPLES}

The average maximum dry densities of the fouled ballast samples varied significantly depending on the amount of fouling. For the track dust fouled ballast, the average dry density was as low as $1,954 \mathrm{~kg} / \mathrm{m}^{3}$ at $10 \%$ fouling and increased to a peak value of $2,114 \mathrm{~kg} / \mathrm{m}^{3}$ for $30 \%$ fouling by weight. Similarly, the average maximum dry densities for the coal dust fouled ballast and the subgrade soil fouled ballast were $1,922 \mathrm{~kg} / \mathrm{m}^{3}$ and $2,050 \mathrm{~kg} / \mathrm{m}^{3}$ for $10 \%$ fouling and $20 \%$ fouling by weight, respectively. The test results of the mechanical properties are discussed below.

\section{CBR}

Fig. 6 shows the CBR results obtained from the DCP tests of the fouled ballast samples at different moisture contents. The CBR values varied only slightly for low moisture contents (up to 5-6\%) for all types of fouled ballast at all fouling percentages. When the moisture contents exceeded a certain value, the CBR decreased dramatically. This value was between 5 and $6 \%$ and referred to as the "optimum moisture content of fouled ballast" $\left(\mathrm{OMC}_{\mathrm{FB}}\right)$. The highest measured $\mathrm{CBR}$ value of the subgrade soil fouled ballast was at $20 \%$ fouling by weight, while the highest CBR values for the track dust fouled ballast and the coal dust fouled ballast were at $30 \%$ and $10 \%$ fouling by weight, respectively. These results were consistent with the maximum dry densities of the fouled ballast samples because both results reached their maximum values at 10,20, and $30 \%$ for coal dust, subgrade, and fouled ballast, respectively. The CBR values for the subgrade soil, track dust, and coal dust fouled ballast at the moisture contents lower than the $\mathrm{OMC}_{\mathrm{FB}}$ were 9 to $11.8,10.3$ to 13 , and 8.6 to 9.6, respectively. All track dust fouled ballast samples possessed relatively high strengths up to the $\mathrm{OMC}_{\mathrm{FB}}$ as compared to the samples fouled with the corresponding percentage of subgrade soil or coal dust. The CBR value of the coal dust fouled ballast did not decrease with increasing moisture content above the $\mathrm{OMC}_{\mathrm{FB}}$ as quickly as the other two types of fouled ballast.

Fig. 6 shows that the fouled ballast lost a substantial percentage of its shear strength when the moisture content exceeded the $\mathrm{OMC}_{\mathrm{FB}}$. The rate of strength loss was highest for the track dust fouled ballast, followed by the subgrade soil fouled ballast and then the coal dust fouled ballast. Because of the lower $\mathrm{OMC}_{\mathrm{FB}}$ value of the track dust fouled ballast, the track dust fouled ballast experienced earlier loss of strength with increasing moisture content as compared with the other fouling agents.

\section{Dynamic Deformation Modulus}

Fig. 7 shows the relationship between the moisture content and dynamic deformation modulus. The maximum dynamic deformation 
FIG. 6 (a) Moisture content versus CBR for the ballast fouled by subgrade soil, (b) moisture content versus CBR for the ballast fouled by track dust and (c) moisture content versus CBR for the ballast fouled by coal dust.

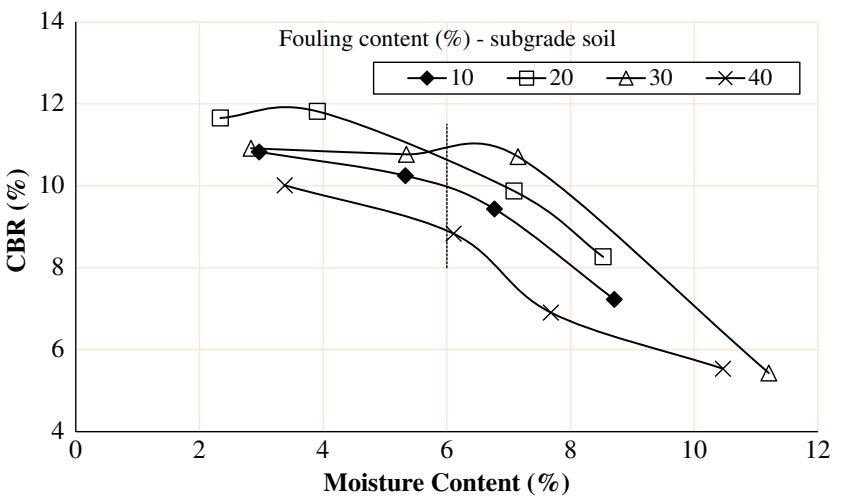

(a)

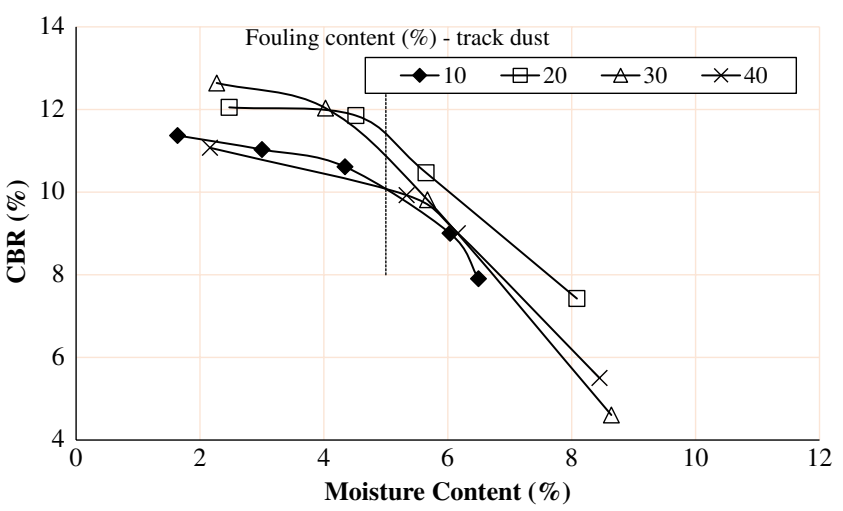

(b)

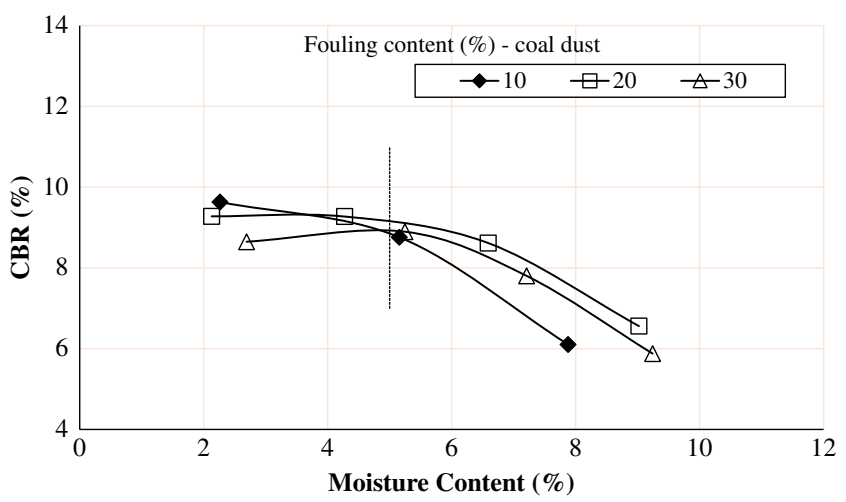

(c)

moduli at various percentages of fouling for the subgrade soil, track dust, and coal dust fouled ballasts occurred at moisture contents consistent with the $\mathrm{OMC}_{\mathrm{FB}}$ values (5-7 \%) for various samples. The moisture content corresponding to the maximum dynamic deformation modulus depended on the amount of fouling present in the ballast and varied from $5 \%$ to $7 \%$ for the subgrade soil fouled ballast, $4.3 \%$ to $5.7 \%$ for the track dust fouled ballast, and $5.3 \%$ to $6.5 \%$ for the coal dust fouled ballast. Fig. 7 shows that the moduli of
FIG. 7 (a) Dynamic deformation modulus versus moisture content for the ballast fouled by subgrade soil, (b) dynamic deformation modulus versus moisture content for the ballast fouled by track dust, and (c) dynamic deformation modulus versus moisture content for the ballast fouled by coal dust.

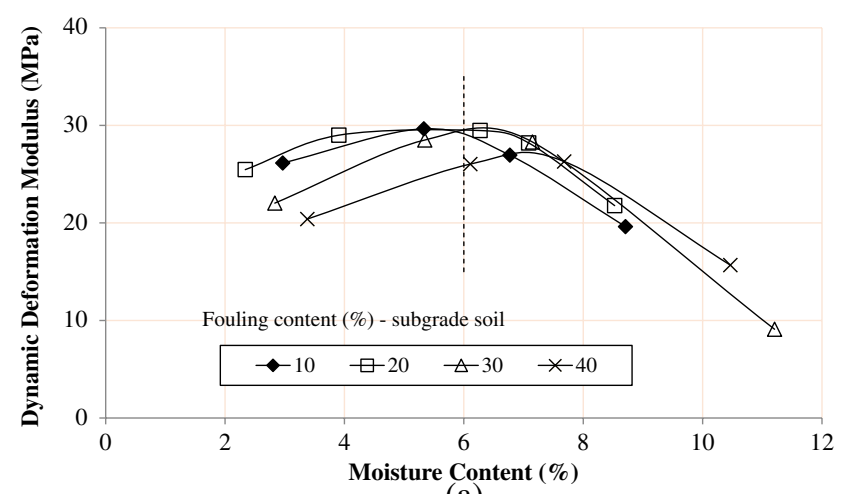

(a)

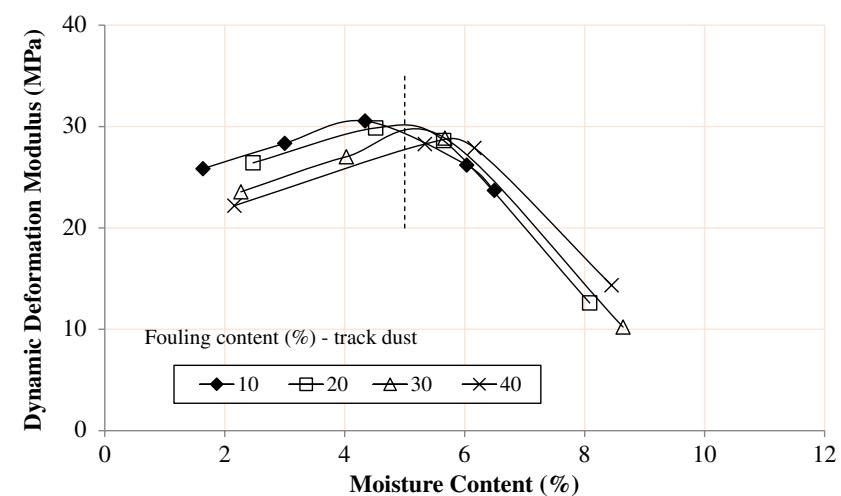

(b)

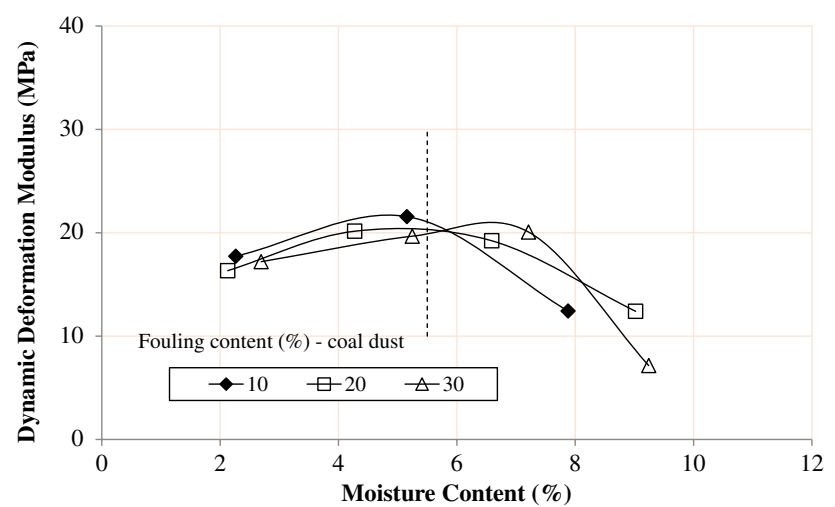

(c)

the ballast decreased when the moisture content was higher than the $\mathrm{OMC}_{\mathrm{FB}}$ values.

The dynamic deformation modulus of the clean ballast was not sensitive to moisture because it contained no fine particles. This modulus was relatively low (approximately 17.2 $\mathrm{MPa}$ ) as compared with the maximum dynamic deformation modulus of the subgrade soil fouled ballast $(29.6 \mathrm{MPa})$, the track dust fouled ballast $(30.5 \mathrm{MPa})$, and the coal dust fouled ballast (21.6 MPa). The track dust fouled ballast had the highest dynamic 
deformation modulus compared with the other two types of fouling. However, the modulus of the track dust fouled ballast decreased more quickly with increasing moisture content above the $\mathrm{OMC}_{\mathrm{FB}}$ than the moduli for the subgrade soil fouled ballast and the coal dust fouled ballast. The trend of the dynamic deformation modulus with increasing moisture content was similar to that for the CBR when the moisture content was higher than $\mathrm{OMC}_{\mathrm{FB}}$. Unlike the $\mathrm{CBR}$, however, the dynamic deformation modulus of the fouled ballast decreased with the decrease of moisture content when the moisture content was lower than $\mathrm{OMC}_{\mathrm{FB}}$.

\section{Subgrade Reaction Modulus}

The applied pressure versus settlement curves obtained from laboratory plate loading tests were plotted to estimate the subgrade reaction modulus. The representative plots of applied pressure versus settlement for ballast samples with $10 \%$ fouling with subgrade soil, track dust, and coal dust are presented in Fig. 8a, b, and c, respectively. The slopes of the initial pressure-displacement curves were determined by drawing a "best-fit" straight line that passed through the origin. The slopes of these lines are the reported subgrade reaction moduli of the test samples.

Fig. 9 presents the subgrade reaction modulus versus moisture content curves for different percentages and types of fouling. The test results showed that the subgrade reaction modulus peaked at approximately the $\mathrm{OMC}_{\mathrm{FB}}$ values. The shapes of the subgrade reaction modulus-moisture content curves are similar to those of the dynamic deformation modulus and moisture content curves as shown in Fig. $\mathbf{7}$.

The subgrade reaction modulus of the track dust fouled ballast was higher than the moduli for the subgrade soil fouled ballast and the coal dust fouled ballast. The moisture content corresponding to the maximum subgrade reaction modulus was lowest for the track dust fouled ballast and was highest for the subgrade soil fouled ballast for the same percentage of fouling. The trend of the subgrade reaction modulus with moisture content for the fouled ballast was similar to that of the dynamic deformation modulus.

\section{Correlation of Mechanical Properties}

Fig. 10a shows the correlation between the dynamic deformation modulus and the subgrade reaction modulus. The $R^{2}$ values for the subgrade soil, track dust, and coal dust fouled ballast were $0.87,0.74$, and 0.82 , respectively, which show reasonable correlation between these two properties.

Fig. 10b shows the correlation between the dynamic deformation modulus and CBR. This correlation is not as strong as that between the subgrade reaction modulus and the dynamic deformation modulus, as demonstrated by the $R^{2}$ values (i.e., 0.54 for the subgrade soil fouled ballast, 0.55 for the track dust fouled ballast, and 0.63 for the coal dust fouled ballast).

Fig. 10c shows the correlation between the CBR and the subgrade reaction modulus. The $R^{2}$ values were 0.67 for the subgrade
FIG. 8 Applied pressure versus settlement of plate loading tests for the ballast fouled by $10 \%$ of (a) subgrade soil, (b) track dust, and (c) coal dust.

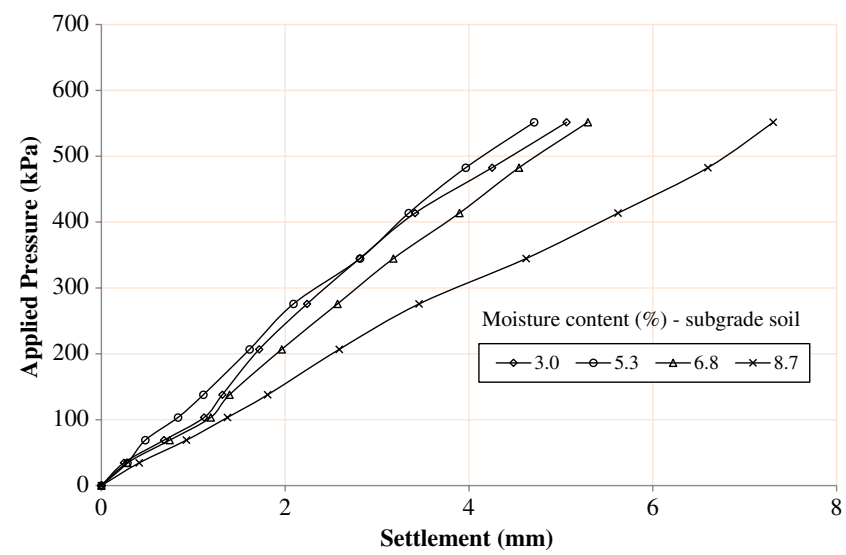

(a)

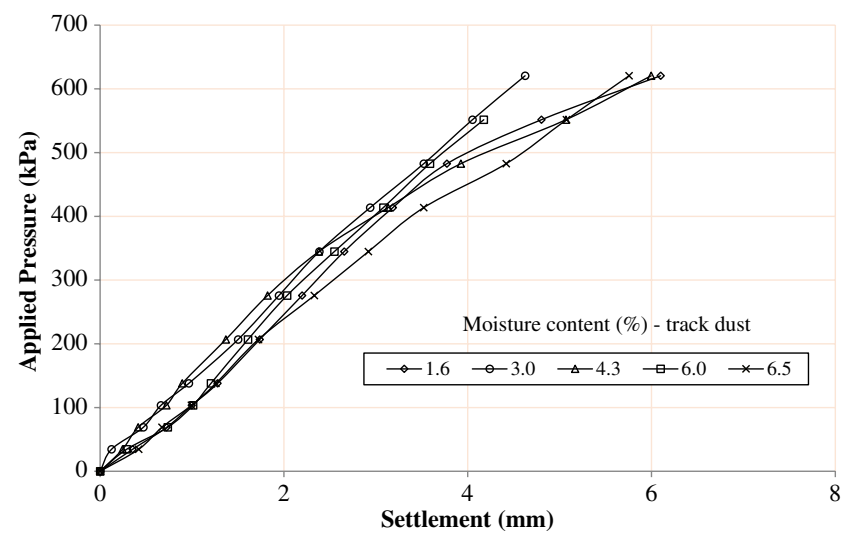

(b)

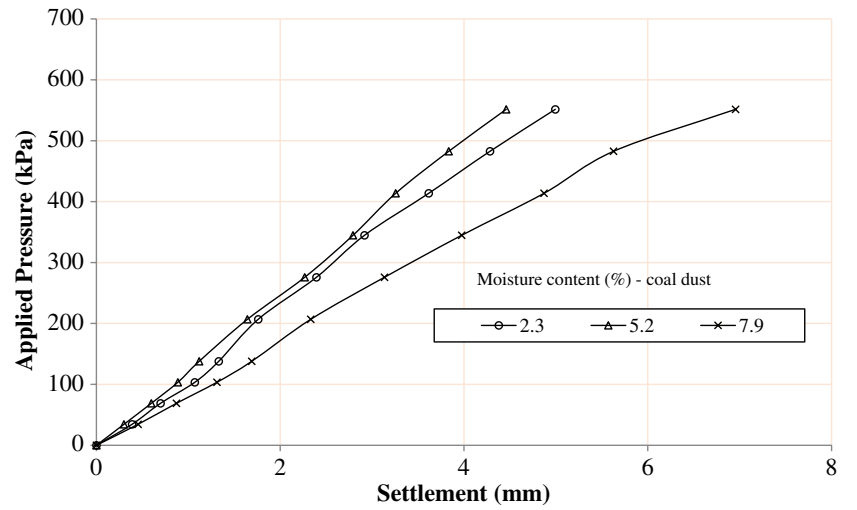

(c)

soil fouled ballast, 0.46 for the track dust fouled ballast, and 0.69 for the coal dust fouled ballast.

\section{Discussion}

LWD and DCP tests are in situ tests that can be conducted quickly and used to assess the strength and modulus of the ballast. Based 
FIG. 9 (a) Subgrade reaction modulus versus moisture content for the ballast fouled by subgrade soil, (b) subgrade reaction modulus versus moisture content for the ballast fouled by track dust, and (c) subgrade reaction modulus versus moisture content for the ballast fouled by coal dust.

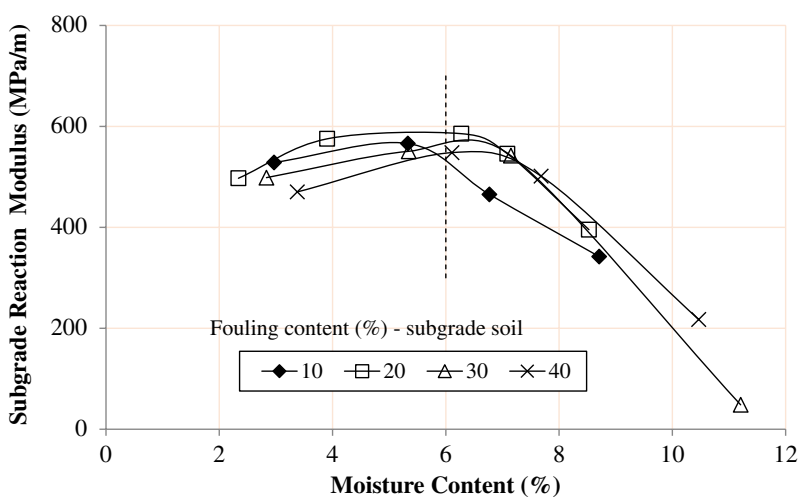

(a)

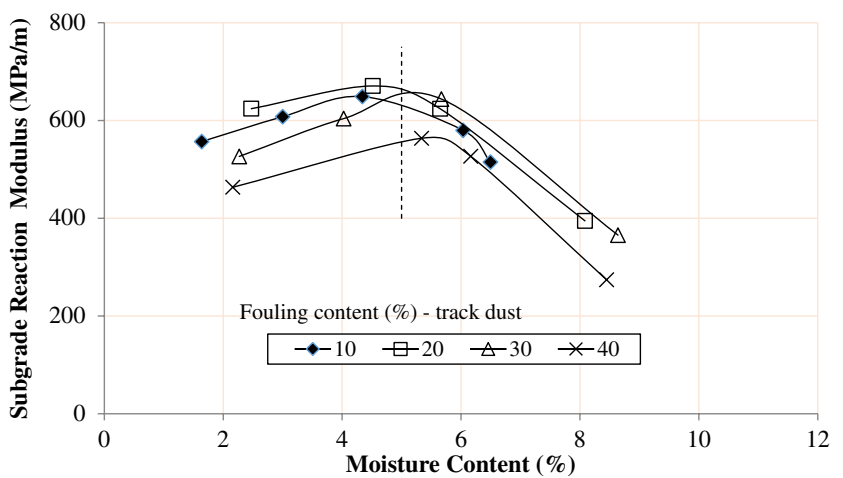

(b)

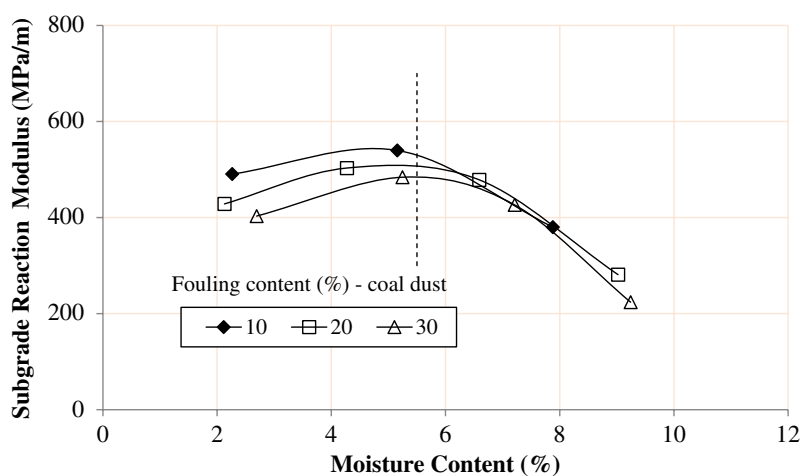

(c)

on the results presented in this article, the mechanical properties were affected by both fouling and moisture; however, moisture content had a greater effect. In addition to reducing the strength of the ballast, fouling minimized the permeability of the ballast, thus reducing its drainage capacity, and promoted higher water content because of higher fine contents. For the clean or lightly fouled ballast (fouling content $\leq 10 \%$ ), the ballast could not hold much moisture because the field capacity of the ballast was quite low. This is particularly true for the ballast dust and the subgrade
FIG. 10 (a) Correlation of dynamic deformation and subgrade reaction moduli, (b) correlation of dynamic deformation modulus and CBR, and (c) correlation of subgrade reaction modulus and CBR.

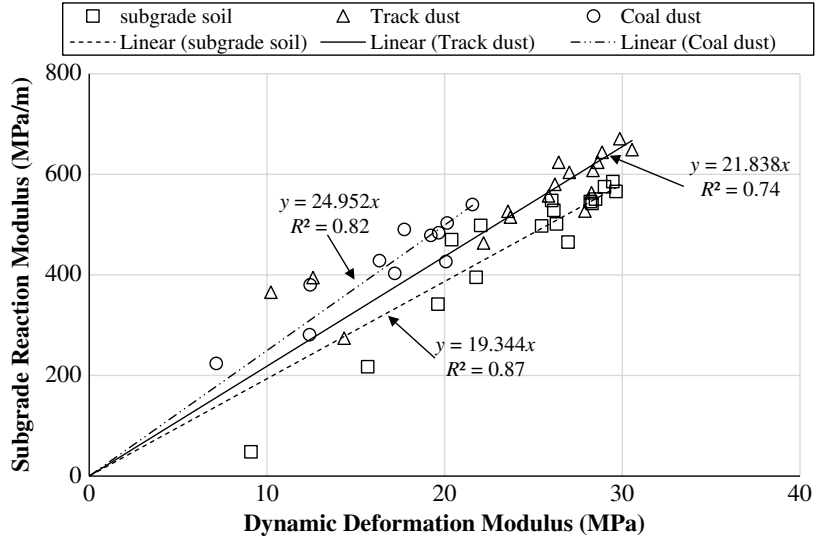

(a)

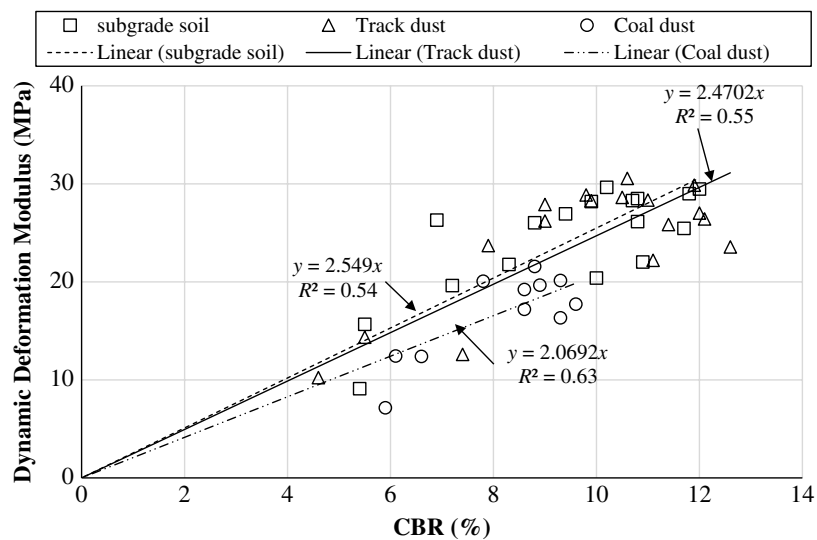

(b)

\begin{tabular}{|c|c|c|}
\hline $\begin{array}{c}\square \text { subgrade soil } \\
- \text { Linear (subgrade soil) }\end{array}$ & $\begin{array}{cl}\Delta & \text { Track dust } \\
& \text { Linear (Track dust) }\end{array}$ & $\begin{array}{l}\text { Coal dust } \\
\text { Linear (Coal dust) }\end{array}$ \\
\hline
\end{tabular}

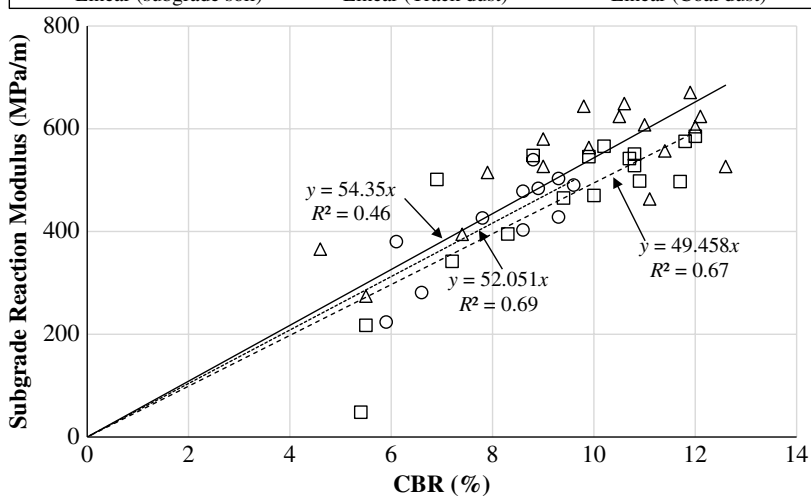

(c)

soil fouling agents, as shown in Figs. 6, 7, and 9. However, coal dust occupied a much larger volume in the fouled ballast for a given weight because it had a much lower specific gravity. The data in these figures also indicate that poor ballast performance requires substantial amounts of water and fouling agent in the ballast. 


\section{Conclusions}

LWD, DCP, and static plate loading tests were conducted in this study to investigate the effects of fouling type and content and moisture content on the mechanical properties of ballast. The mechanical properties include the CBR, the dynamic deformation modulus, and the subgrade reaction modulus of the ballast. The following conclusions can be made from this study:

1. The highest CBR values were found at $20 \%$ fouling content by weight in the subgrade soil fouled ballast, $30 \%$ fouling content by weight in the track dust fouled ballast, and $10 \%$ fouling content by weight in the coal dust fouled ballast at their corresponding optimum moisture contents $\left(\mathrm{OMC}_{\mathrm{FB}}\right)$. The $\mathrm{CBR}$ values decreased significantly when the moisture content exceeded the $\mathrm{OMC}_{\mathrm{FB}}$, which was about 5-6\% for all types and contents of fouling. The track dust fouled ballast lost its mechanical properties more quickly as the moisture content increased above the $\mathrm{OMC}_{\mathrm{FB}}$ as compared with other two types of fouling agents. The coal dust fouled ballast had a smaller CBR value as compared with the subgrade soil fouled ballast and the track dust fouled ballast.

2. The dynamic deformation modulus and the subgrade reaction modulus also had $\mathrm{OMC}_{\mathrm{FB}}$ values. These $\mathrm{OMC}_{\mathrm{FB}}$ values varied slightly with the fouling content. The high dynamic deformation modulus of the track dust fouled ballast occurred within a narrower range of moisture content as compared with the subgrade soil fouled ballast and the coal dust fouled ballast. The track dust fouled ballast had the highest maximum dynamic deformation modulus, followed by the subgrade soil fouled ballast and the coal dust fouled ballast for the same fouling content by weight. For the same fouling content by weight, the track dust fouled ballast had the highest subgrade reaction modulus at OMCFB, followed by the subgrade soil fouled ballast, and then the coal dust fouled ballast; the maximum percentage difference of the peak modulus values among these materials was $25 \%$. These peak values were within a fairly narrow range $(540-675 \mathrm{MPa} / \mathrm{m})$. The subgrade reaction moduli and dynamic deformation moduli had good correlation for all types of fouling agents. The correlation between the CBR and the subgrade reaction modulus or dynamic deformation modulus was present, but not as strong, when compared with the above correlations.

\section{ACKNOWLEDGMENTS}

The authors would like to thank the Mid-America Transportation Center for providing financial support for this research, Mr. Hank Lees at the BNSF Railway for providing the material, and Matthew Maksimowicz, Eric Nicholson, David Woody, and Zachary Aaron Brady at the University of Kansas for providing the technical support and physical help to run the tests in this research.

\section{References}

Ayers, M. E., Thompson, M. R., and Uzarski, D. R., 1989, "Rapid Shear Strength Evaluation of In Situ Granular Materials," Transp. Res. Rec., Vol. 1227, pp. 134-146.

Chen, D.-H., Lin, D.-F., Liau, P.-H., and Bilyeu, J., 2005, “A Correlation between Dynamic Cone Penetrometer Values and Pavement Layer Moduli," Geotech. Test. J., Vol. 28, No. 1, pp. 42-49, https://doi.org/10.1520/GTJ12312

Ebrahimi, A., Tinjum, J. M., and Edil, T. B., 2014, "Deformational Behavior of Fouled Railway Ballast," Can. Geotech. J., Vol. 52, No. 3, pp. 344-355, https://doi.org/10.1139/cgj-2013-0271

Harison, J. A., 1987, “Correlation between California Bearing Ratio and Dynamic Cone Penetrometer Strength Measurement of Soils," Proc. Inst. Civ. Eng., Vol. 83, No. 4, pp. 833-844.

Hay, W. W., 1982, Railroad Engineering, 2nd ed., Wiley, New York, 758p.

Herrick, J. E. and Jones, T. L., 2002, "A Dynamic Cone Penetrometer for Measuring Soil Penetration Resistance," Soil Sci. Soc. Am. J., Vol. 66, pp. 1320-1324, https://doi.org/ $10.2136 /$ sssaj2002.1320

Huang, H. and Tutumluer, E., 2011, "Discrete Element Modeling for Fouled Railroad Ballast," Constr. Build. Mater., Vol. 25, No. 8, pp. 3306-3312, https://doi.org/10.1016/j.conbuildmat. 2011.03.019

Huang, H., Tutumluer, E., and Dombrow, W., 2009, "Laboratory Characterization of Fouled Railroad Ballast Behavior," Transp. Res. Rec., Vol. 2117, pp. 93-101, https://doi.org/10.3141/ 2117-12

Indraratna, B., Khabbaz, H., Salim, W., and Christie, D., 2006, "Geotechnical Properties of Ballast and the Role of Geosynthetics in Rail Track Stabilization," Proc. Inst. Civ. Eng. Ground Improv., Vol. 10, No. 3, pp. 91-101, https:// doi.org/10.1680/grim.2006.10.3.91

Lekarp, F., Isacsson, U., and Dawson, A., 2000, "State of Art. I: Resilient Response of Unbound Aggregates," J. Transp. Eng., Vol. 126, No. 1, pp. 66-75, https://doi.org/10.1061/ (ASCE)0733-947X(2000)126:1(66)

Mazari, M., Tirado, C., Abdallah, I., and Zazarian, S., 2016, "Mechanistic Estimation of Lightweight Deflectometer Target Field Modulus for Construction Quality Control," Geotech. Test. J., Vol. 39, No. 6, pp. 965-976, https://doi. org/10.1520/GTJ20150266

Mohammad, L. N., Nazzal, M. D., Abu-Farsakh, M. Y., and Alshibli, K., 2009, "Estimation of Subgrade Soils Resilient Modulus from In-Situ Devices Test Results," J. Test. Eval., Vol. 37, No. 3, pp. 245-253, https://doi.org/10.1520/JTE101993

Mooney, M. A. and Miller, P. K., 2009, “Analysis of Lightweight Deflectometer Test Based on In Situ Stress and Strain Response," J. Geotech. Geoenviron. Eng., Vol. 135, No. 2, pp. 199-208, https://doi.org/10.1061/(ASCE)1090-0241 (2009)135:2(199)

Parsons, R., Rahman, A. J., and Han, J., 2012, Properties of Fouled Railroad Ballast (Phase 1), Report \#MATC-KU: 465, MidAmerica Transportation Center, Lincoln, NE, 55p.

Parsons, R., Rahman, A., Han, J., and Glavinich, T., 2014, "Track Ballast Fouling and Permeability Characterization by Using Resistivity," Transp. Res. Rec., Vol. 2448, pp. 133-141, https://doi.org/10.3141/2448-16 
Read, D., Hyslip, J., McDaniel, R., and Lees, H., 2010, "Track Substructure Research-Ballast Fouling Investigation," Railway Track Struct., Vol. 106, No. 12, pp. 19-23.

Salgado, R. and Yoon, S., 2003, Dynamic Cone Penetration Test for Subgrade Assessment, Report FHWA/IN/JTRP-2002/30, Joint Transportation Research Program, Indiana Department of Transportation and Purdue University, West Lafayette, IN, 108p, https://doi.org/10.5703/1288284313196

Umashankar, B., Hariprasad, C., and Kumar, G. T., 2016, "Compaction Quality Control of Pavement Layers Using LWD," J. Mater. Civ. Eng., Vol. 28, No. 2, pp. 04015111-1-04015111-8, https://doi.org/10.1061/(ASCE)MT.1943-5533.0001379
Wallace, A. J., 2003, "Permeability of Fouled Ballast," U.G. thesis, University of Wollongong, Wollongong, Australia.

Webster, S. L., Brown, R. W., and Porter, J. R., 1994, Force Projection Site Evaluation Using the Electric Cone Penetrometer (ECP) and the Dynamic Cone Penetrometer (DCP), Technical Report GL-94-17, U.S. Air Force Civil Engineering Supply Agency, Tyndall AFB, FL, 174p.

Zorn Instruments, 2011, "User Manual for the Light Weight Deflectometer (LWD), ZFG 3.0," Zorn Instruments, Stendal, Germany, 32p. 